\title{
Past and future snowmelt trends in the Swiss Alps: the role of temperature and snowpack
}

\author{
Maria Vorkauf $^{1}$ (D) $\cdot$ Christoph Marty $^{2} \cdot$ Ansgar Kahmen $^{1} \cdot$ Erika Hiltbrunner $^{1}$
}

Received: 4 August 2020 / Accepted: 4 February 2021 / Published online: 9 April 2021

(C) The Author(s) 2021

\begin{abstract}
The start of the growing season for alpine plants is primarily determined by the date of snowmelt. We analysed time series of snow depth at 23 manually operated and 15 automatic (IMIS) stations between 1055 and $2555 \mathrm{~m}$ asl in the Swiss Central Alps. Between 1958 and 2019, snowmelt dates occurred $2.8 \pm 1.3$ days earlier in the year per decade, with a strong shift towards earlier snowmelt dates during the late 1980s and early 1990s, but non-significant trends thereafter. Snowmelt dates at high-elevation automatic stations strongly correlated with snowmelt dates at lower-elevation manual stations. At all elevations, snowmelt dates strongly depended on spring air temperatures. More specifically, $44 \%$ of the variance in snowmelt dates was explained by the first day when a threeweek running mean of daily air temperatures passed a $5{ }^{\circ} \mathrm{C}$ threshold. The mean winter snow depth accounted for $30 \%$ of the variance. We adopted the effects of air temperature and snowpack height to Swiss climate change scenarios to explore likely snowmelt trends throughout the twenty-first century. Under a high-emission scenario (RCP8.5), we simulated snowmelt dates to advance by 6 days per decade by the end of the century. By then, snowmelt dates could occur one month earlier than during the reference periods (1990-2019 and 2000-2019). Such early snowmelt may extend the alpine growing season by one third of its current duration while exposing alpine plants to shorter daylengths and adding a higher risk of freezing damage.
\end{abstract}

Keywords Climate change $\cdot$ Scenario modelling $\cdot$ Time series analysis $\cdot$ Growing season $\cdot$ Highelevation $\cdot$ Snowmelt $\cdot$ Alps

\section{Introduction}

The growing season of alpine plants above the climatic treeline is closely tied to snowmelt dates (Körner 2021; Hülber et al. 2010; Wipf and Rixen 2010). Therefore, the mostly long-

Maria Vorkauf

evamaria.vorkauf@unibas.ch

Extended author information available on the last page of the article 
lived alpine perennials only have about three months for their seasonal development, but there is a high local variability due to the complex topography and substantial snow redistribution by wind in winter. Most of an alpine plant's growth occurs during the first few snow-free weeks (Körner 2021). In the core of the alpine vegetation belt of the Swiss Alps at $2500 \mathrm{~m}$ asl, peak aboveground biomass is commonly reached in early August; thereafter, photoperiod signals (daylength) trigger the resorption of nutrients from leaves (Prock and Körner 1996), followed by plant tissue senescence. The meristems of alpine plants (tissues for growth) are located a few centimeters below the ground surface and insulating snow during winter prevents soil freezing (Körner 2021). Freezing of alpine soils may alter nutrient relations by physical degradation of soil organic matter and retention of nutrients such as inorganic nitrogen (Edwards et al. 2007; Freppaz et al. 2008; Baptist et al. 2010a). Changes in the duration of the snow cover, particularly in snowmelt dates are thus relevant for plant development and nutrient cycling in alpine ecosystems. However, not all alpine species may profit from earlier snowmelt, as their development may be constrained by short photoperiods (Heide 2001; Keller and Körner 2003).

\subsection{Decline in the snow cover}

Recent climatic changes have affected the seasonal snow cover (Hock et al. 2019) and raised the concern of various stakeholders (Beniston et al. 2018), as the snowpack is crucially important for skiing and meltwater runoff affects hydropower production (Westaway 2000). In Switzerland, the number of days with snowpack reached a minimum in the late 1980s, based on 100-year snow series from five stations between 450 and $1860 \mathrm{~m}$ asl (Scherrer et al. 2013). These reductions were mainly explained by rising temperatures (Scherrer et al. 2004). By the end of the twenty-first century, a continuous snow cover of more than 30 days will be rare in the Swiss Alps below $1600 \mathrm{~m}$ asl, and the mean snow depth (Dec-Feb) is predicted to decline by $74 \%$. Even the high-elevation station Weissfluhjoch at $2540 \mathrm{~m}$ asl may undergo reductions in snow depth of 23\% (Schmucki et al. 2015a). This station's snow depth has been considered to be representative for high-elevation sites (2000-2900 m asl) in Switzerland (Marty and Meister 2012).

Past trends in snowmelt dates, which are crucial for the alpine plant development, were assessed by Klein et al. (2016), but the analysis was restricted to 45 years and to one site in the alpine vegetation belt only. Furthermore, to predict the functioning of alpine ecosystems under climate change, it is necessary to project future snowmelt dates for the alpine vegetation zone.

\subsection{Main objectives}

We assess trends in snow onset and snowmelt between 1958 and 2019, focusing on 38 snow measurement stations between 1055 and $2555 \mathrm{~m}$ asl in the Swiss Central Alps. This is a core region for winter tourism, hydropower generation, but also longer-term research projects (Körner et al. 2019). Because most time series for snowmelt dates are not longer than 20 years at high-elevation sites, we elaborate the correlation of snowmelt dates at 15 automatic stations above $2100 \mathrm{~m}$ asl (daily median of $30 \mathrm{~min}$ intervals) with manually measured longterm series of daily snow depth data at 23 stations (mainly below $1500 \mathrm{~m}$ asl). A main goal of this study was to evaluate the role of air temperatures and of the mean winter snow depth on snowmelt dates in order to predict future trends in snowmelt dates. Owing to fast melting of the snowpack in spring, we hypothesise that snowmelt dates are largely determined by the time 
when mean air temperatures exceed a threshold, yet to be identified. We expect that the mean winter snow depth regulates snowmelt dates in years with exceptionally high or low snow depth. We then apply the identified drivers of past snowmelt dates to the Swiss climate change scenarios (CH2018) to predict the onset of the alpine growing season throughout the twentyfirst century.

\section{Methods}

\subsection{Station types}

We analysed snow depth measurements of 38 stations between 1055 and $2555 \mathrm{~m}$ asl in the Swiss Central Alps to derive time series of dates of snow onset and melt (see Table 1 for list of stations). We used two types of stations: manually operated (MAN) and automatic stations. MAN stations are often below $1500 \mathrm{~m}$ asl, operated by the Federal Office of Meteorology and Climatology MeteoSwiss and by the WSL Institute for Snow and Avalanche Research (SLF). Snow depth readings are taken daily and many time series date back to the 1950s. Automatic stations were established to improve the Swiss avalanche warning system (Intercantonal Measurement and Information System IMIS). IMIS stations are typically located above $2000 \mathrm{~m}$ asl, often close to avalanche starting zones. For most of these stations, the first fully operational year was 2000. In addition to wind and temperature (air and ground), snow depth is measured by an ultrasonic sensor (SR50, Campbell Scientific, US; every 30 minutes). Both station types are typically located in relatively flat terrain. We utilised daily snow depth measurements from 23 MAN stations (morning readings) and 15 IMIS stations (daily median of 30 min snow depth values; Table 1). We included two stations outside of the Swiss Central Alps because of their long-term data series since 1936 and 1952, respectively (Fig. 1: $5 \mathrm{WJ}, 4 \mathrm{MO})$.

\subsection{Definition of snow onset and melt}

We defined snow onset and melt dates as the first and the last day of the main snow period. The main snow period corresponded to the longest period of snow cover in a hydrological year (e.g. year 1991 runs from 1 Sept 1990 to 31 Aug 1991). Owing to the two measurement techniques for snow depth and the distinct elevations, we performed different approaches to identify the main snow period of MAN and IMIS stations, respectively.

At lower elevations with MAN stations, snow-free days during winter are not uncommon; therefore, the main snow period is less clearly identifiable. For these stations, we allowed the main snow period to contain days without snow cover, but not more than 5 consecutive days. We also tested maximum gaps of 1, 3 and 10 days.

IMIS stations at high elevations with low winter temperatures show a distinct main snow period. Thus, it was unnecessary to include snow-free days for the main snow period. However, the ultrasonic signal is scattered and often exhibits an offset, impeding a clear differentiation between snow cover and ground surface. Therefore, we implemented a procedure that recognises this offset and then deduces the main snow period, including snow onset and melt dates ( $\mathrm{R}$ function in Online Resource 1). To suppress the scattering, we used 5-day running means of snow depth. The snow depth signal just after snowmelt was usually less variable than for snow cover; thus, we looked for periods with relatively constant ultrasonic 
Table 1 General description of all 38 stations used for identifying the snow onset and melt date, with elevation, coordinates and operational years in the Swiss Central Alps

\begin{tabular}{|c|c|c|c|c|c|c|c|}
\hline Type & Abbr. & Site name & $\begin{array}{l}\text { Ele- } \\
\text { vation }\end{array}$ & $\begin{array}{l}\text { Latitude, } \\
\text { Longitude }\end{array}$ & Canton & $\begin{array}{l}\text { Operational } \\
\text { years }\end{array}$ & Provider \\
\hline MAN & GTT & Guttannen & 1055 & $46.6565,8.2917$ & $\mathrm{BE}$ & 1948-2019 & MS \\
\hline MAN & $2 \mathrm{EN}$ & Engelberg & 1060 & $46.8189,8.4240$ & $\mathrm{BE}$ & 1950-2019 & SLF a) \\
\hline MAN & GOS & Goeschenen & 1099 & $46.6676,8.5811$ & UR & 1960-2019 & MS a) \\
\hline MAN & AIR & Airolo & 1139 & $46.5260,8.5974$ & $\mathrm{TI}$ & 1959-2019 & MS \\
\hline MAN & $1 \mathrm{GA}$ & Gadmen & 1190 & $46.7367,8.3523$ & $\mathrm{BE}$ & 1955-2019 & SLF \\
\hline MAN & DIS & Disentis & 1197 & $46.7065,8.8534$ & GR & 1953-2019 & MS \\
\hline MAN & $6 \mathrm{CB}$ & Campo Blenio & 1215 & $46.5554,8.9367$ & $\mathrm{TI}$ & 1953-2019 & SLF \\
\hline MAN & $1 \mathrm{WE}$ & Wengen & 1280 & $46.6064,7.9213$ & $\mathrm{BE}$ & 1947-2019 & SLF \\
\hline MAN & $2 \mathrm{ME}$ & Meien & 1320 & $46.7245,8.5568$ & UR & 1954-2019 & SLF \\
\hline MAN & $4 \mathrm{UL}$ & Ulrichen & 1350 & $46.5049,8.3083$ & VS & 1942-2019 & SLF \\
\hline MAN & $40 W$ & Oberwald & 1370 & $46.5322,8.3503$ & VS & 1967-2019 & SLF \\
\hline MAN & $4 \mathrm{MS}$ & Muenster & 1410 & $46.4904,8.2638$ & VS & 1946-2019 & SLF \\
\hline MAN & $5 \mathrm{SE}$ & Sedrun & 1420 & $46.6794,8.7688$ & GR & 1977-2019 & SLF \\
\hline MAN & $2 \mathrm{AN}$ & Andermatt & 1440 & $46.6332,8.5919$ & UR & 1941-2019 & SLF \\
\hline MAN & $2 \mathrm{GA}$ & Goescheneralp & 1550 & $46.6518,8.5182$ & GR & 1989-2019 & SLF \\
\hline MAN & $1 \mathrm{~GB}$ & Grindelwald Bort & 1565 & $46.6473,8.0514$ & $\mathrm{BE}$ & 1948-2019 & SLF \\
\hline MAN & $4 \mathrm{MO}$ & Montana & 1590 & $46.3138,7.4770$ & VS & 1952-2019 & SLF \\
\hline MAN & $1 \mathrm{MR}$ & Muerren & 1650 & $46.5584,7.8902$ & $\mathrm{BE}$ & 1948-2019 & SLF \\
\hline MAN & 6RI & Ritom Piora & 1800 & $46.5272,8.6722$ & TI & 1957-2019 & SLF \\
\hline MAN & $\mathrm{GRH}^{\mathrm{b})}$ & Grimsel Hospitz & 1980 & $46.5715,8.3328$ & $\mathrm{BE}$ & 1950-2019 & SLF \\
\hline IMIS & BED3 & Cassinello & 2101 & $46.4912,8.5219$ & TI & 1998-2019 & SLF \\
\hline MAN & GOT & Gotthard & 2107 & $46.5543,8.5663$ & TI & 1936-1970 & MS \\
\hline IMIS & URS2 & Giltnasen & 2169 & $46.5871,8.5138$ & UR & 1998-2019 & SLF \\
\hline IMIS & OBW3 & Maellige & 2194 & $46.5078,8.3543$ & VS & 2000-2019 & SLF \\
\hline IMIS & PUZ2 & Ils Plauns & 2196 & $46.6262,8.8626$ & GR & 1997-2019 & SLF \\
\hline IMIS & TUJ3 & Nual & 2211 & $46.6471,8.7402$ & GR & 1998-2019 & SLF \\
\hline IMIS & MEI2 & Laucheren & 2220 & $46.7435,8.5509$ & UR & 1998-2019 & SLF \\
\hline IMIS & TUJ2 & Culmatsch & 2262 & $46.6843,8.7236$ & GR & 1998-2019 & SLF \\
\hline IMIS & VAL2 & Vallascia & 2268 & $46.5492,8.6135$ & TI & 1997-2019 & SLF \\
\hline \multirow[t]{2}{*}{ MAN } & $\mathrm{GUE}^{\mathrm{c})}$ & Guetsch & 2287 & $46.6535,8.6162$ & UR & 1958-2003 & MS \\
\hline & & & 2,283 & $46.6524,8.6150$ & & 2009-2019 & \\
\hline IMIS & LUM2 & Lumpegna & 2388 & $46.7317,8.8621$ & GR & 1998-2019 & SLF \\
\hline IMIS & GOM3 & Treichbode & 2427 & $46.4891,8.2286$ & VS & $2000-2019$ & SLF \\
\hline IMIS & OBW2 & Jostsee & 2432 & $46.5454,8.3161$ & VS & 2000-2019 & SLF \\
\hline IMIS & GOM2 & Bodmerchumma & 2439 & $46.4212,8.2328$ & VS & 2000-2019 & SLF \\
\hline IMIS & BED2 & Cavanna & 2450 & $46.5340,8.5108$ & TI & 1997-2019 & SLF \\
\hline MAN & $5 \mathrm{WJ}$ & Weissfluhjoch & 2540 & $46.8296,9.8092$ & GR & 1937-2019 & SLF \\
\hline IMIS & WFJ2 & Weissfluhjoch & 2536 & $46.8296,9.8093$ & GR & 2000-2019 & SLF \\
\hline IMIS & LUK2 & Lai Verd & 2555 & $46.6040,8.7830$ & GR & 2000-2019 & SLF \\
\hline
\end{tabular}

Please note that there are locations with more than one station. Stations are ordered by elevation

a) SLF, Institute for Snow and Avalanche Research; MS, Federal Office of Meteorology and Climatology MeteoSwiss

b) HS measurements for the entire main snow period started in 1970

c) The data of two stations were combined to obtain a complete dataset for the location (referred to as one station). At the station GUE the manual measurements were replaced by automatic measurements in 2009

signals to identify the ground surface (offset). Low standard deviations (SD) of the 5-day running windows, both in winter and summer, indicated a period of constant snow depth or a period without snow (ground surface). Of all winter periods with low SD that were longer than 20 days (empirically found), we selected the most frequently occurring snow depth to obtain the height of the ground surface (offset). 


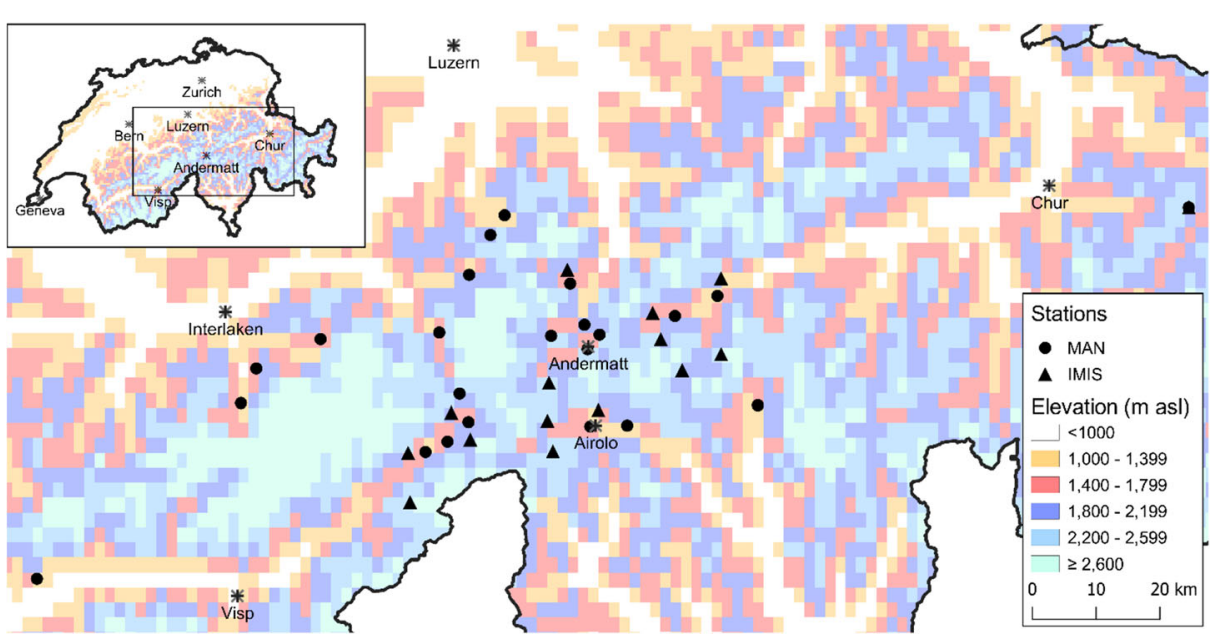

Fig. 1 Map of manual (MAN) and automatic (IMIS) stations and the elevational belts in central Switzerland (villages and cities are presented by an asterisk; digital elevation model of the $\mathrm{CH} 2018$ climate change scenarios, resolution $2 \times 2 \mathrm{~km}$ )

At Weissfluhjoch, a MAN (5WJ) and an IMIS (WFJ2) station run in parallel (Table 1), which enables us to compare the snow onset and snowmelt dates deduced from the definitions for the two station types.

\subsection{Data quality and handling of data gaps}

At MAN stations, the method for measuring snow depth remained unchanged during the observational period. Displacements of the measuring fields have rarely occurred and are not influential (Buchmann et al. 2020). In addition, there were no changes in the sensor type of the IMIS stations nor in measuring fields through dislocations. We visually checked the snow depth data of the IMIS stations and removed obvious outliers from the data series.

For both station types, the few dates with missing snow depth data were interpolated linearly. Overall, 5\% of all observations between 1 October and 1 June were missing. However, some of the MAN stations report missing values over the snow-free season. For the period between the determined snow onset and melt date, only $0.6 \%$ of the data was missing.

Missing snow onset or melt dates of single years were either filled based on correlations with nearby stations at similar elevation and comparable snow depth, or if snow depth towards the end of the main snow period already went below $20 \mathrm{~cm}$, snowmelt dates were extrapolated linearly (Online Resource 2 lists stations and years with interpolated data gaps). In total, our data set included 1198 observations for snowmelt dates, $2.3 \%$ of which were missing.

\subsection{Statistical analyses}

Any trends in time series (onset and melt) were analysed with Theil-Sen slopes and the MannKendall test (R package trend v1.1.2, Pohlert 2020), both relatively robust against outliers. To calculate long-term trends in snow onset and melt dates, we chose the period 1958 to 2019, as it was the longest possible period with snow depth data including two stations above $2000 \mathrm{~m}$ 
asl. This period included 16 out of 23 MAN stations between 1055 and $2555 \mathrm{~m}$ asl with continuous measurements for snow depth.

As snowmelt dates are more decisive for alpine plant development than snow onset, we focussed on snowmelt dates for further analysis. However, both snow onset and snowmelt dates were needed to delineate the main snow cover duration. Short-term trends in snowmelt dates were computed as Theil-Sen slopes by running windows of 21 years for all 23 MAN stations, each covering at least the period 1958-2019 except for GOT at $2107 \mathrm{~m}$ asl (19361970). The trend in year $y$ corresponded to the trend for the years $y-10$ to $y+10$. IMIS stations could not be included in the analysis of running window trends, as they did not cover the required 21 years. Thus, we compared high (IMIS stations) and low-elevation (MAN stations) sites by the Pearson correlation between their snowmelt dates. For each station we computed the yearly deviation of snowmelt dates from its mean between 2000-2019. Thereof, we calculated the yearly mean and SD of the deviation for each station type. A prerequisite for the correlation of time series is the so-called weak stationarity, where the expected mean, variance and covariance do not change over time. A commonly adopted approach is to subtract from each value the value from the previous year (Cryer and Chan 2008). For the so derived first-differences of the snowmelt series, we then calculated the Pearson correlation between snowmelt dates at MAN and IMIS stations.

To project future snowmelt dates, we unravelled the contributions of temperature and snow depth to snowmelt dates by fitting a model including both parameters and their relationships with snowmelt dates. For snow depth, we used the mean snowpack height $\mathrm{HS}_{\text {mean }}$ between snow onset and snowmelt date, available from the daily snow depth measurements. Automatic weather stations (MeteoSwiss) measure the daily mean air temperature $2 \mathrm{~m}$ above ground. For nine of the MAN stations, air temperature measurements from the same location (village), usually within less than $100 \mathrm{~m}$ elevational difference were available: GOS (27; means 27 years of overlapping snow depth and temperature data at a given site), GTT (37), 4UL (39), GRH (50), GUE (58), DIS (59), 5WJ (60), 4MO (68) and 2AN (79). The temperature data have already undergone a semi-automatic quality control, and we used homogeneous data series for GTT, 4UL, GRH, GUE, DIS, 5WJ and 2AN. The 14 IMIS stations recorded air temperatures every 30 minutes during 20 years (WFJ2 was excluded due to the parallel station $5 \mathrm{WJ}$, see Table 1 for abbreviations).

Snowmelt dates differ between stations (elevations) and fluctuate over the years. Thus, the time when temperatures are high enough for snowmelt to occur also varies between stations and years. As we observed that the snow depth rapidly decreases during the last weeks before the snowmelt date, we assumed that the snowmelt date would only occur when air temperatures were high enough for a certain time period. We thus adopted a temperature measure for the first day (day of year DOY) when the daily mean air temperature exceeded $5{ }^{\circ} \mathrm{C}$ in a running window of 21 days $\left(\mathrm{T}_{21 \mathrm{~d}} \geq 5^{\circ} \mathrm{C}\right)$. We empirically found a high correlation of $\mathrm{T}_{21 \mathrm{~d}} \geq 5$ ${ }^{\circ} \mathrm{C}$ with the snowmelt dates $(\mathrm{r}=0.87, p<0.001)$. As snowmelt occurs at temperatures above 0 ${ }^{\circ} \mathrm{C}$ we also tested a threshold of $0{ }^{\circ} \mathrm{C}$ and $3{ }^{\circ} \mathrm{C}$, and for an upper limit we used a threshold of 10 ${ }^{\circ} \mathrm{C}$. Moreover, we tested running windows of 7, 14 and 30 days, and also degree-days with thresholds $>0{ }^{\circ} \mathrm{C}$ and $>5^{\circ} \mathrm{C}$, all yielding weaker correlations (shown in Online Resource 3). Moreover, our prior exploration of the data implied a high linear correlation of the snowmelt dates with the square root of $\mathrm{HS}_{\text {mean }}(\mathrm{r}=0.85, p<0.001)$. We thus fitted the linear mixed model:

$$
S M_{\text {station }}=a^{*} T_{21 d} \geq 5^{\circ} \mathrm{C}+b^{*} \sqrt{H S_{\text {mean }}}+\text { intercept }_{\text {station }}
$$


where $a$ indicates how much the snowmelt date was delayed by an additional day of $\mathrm{T}_{21 \mathrm{~d}} \geq 5$ ${ }^{\circ} \mathrm{C}$ (unit day day $\left.{ }^{-1}\right) ; b$ (day $\mathrm{cm}^{-1 / 2}$ ) describes the non-linear relation of snowmelt dates and the square root of $\mathrm{HS}_{\text {mean }}$, and intercept $t_{\text {station }}$ is the intercept of stations used as random factor. We visually checked residuals of the linear mixed model and excluded 33 data points (outliers) with large residuals and high leverage from the analysis. Because $\mathrm{T}_{21 \mathrm{~d}} \geq 5{ }^{\circ} \mathrm{C}$ and $\mathrm{HS}_{\text {mean }}$ may be correlated, we also calculated the variance inflation factor. This factor indicates how much variance of a variable is influenced (inflated) due to collinearity with another variable. To assess their individual effect on snowmelt dates, we also fitted linear mixed models for either of the two fixed effects, $\mathrm{HS}_{\text {mean }}$ or $\mathrm{T}_{21 \mathrm{~d}} \geq 5^{\circ} \mathrm{C}$. For each model, we derived the marginal $\mathrm{R}_{\mathrm{m}}{ }_{\mathrm{m}}$ that showed the percentage of variance explained by the individual fixed effect, along with the conditional $\mathrm{R}^{2}$ that explained the variance by the fixed and random effects combined $(\mathrm{R}$ package MuMIn v1.43.15; Bartoń, 2020). $\mathrm{R}_{\mathrm{m}}^{2}$ enabled us to quantify the contributions of both, $\mathrm{HS}_{\text {mean }}$ and $\mathrm{T}_{21 \mathrm{~d}} \geq 5^{\circ} \mathrm{C}$ to snowmelt dates.

\subsection{Snowmelt dates in the twenty-first century}

To estimate trends in snowmelt dates for the twenty-first century, we applied the above linear mixed model to the CH2018 Climate Change Scenarios for Switzerland (CH2018 Project Team 2018). These include three Representative Concentration Pathway scenarios, referred to as: RCP2.6 (strong emission reductions, warming limited to $2{ }^{\circ} \mathrm{C}, 12$ simulations), RCP4.5 (declining emissions after $2050,>2{ }^{\circ} \mathrm{C}$ warming compared to pre-industrial times, 25 simulations) and RCP8.5 (unabated emissions, 31 simulations). For these simulations, a total of 31 regional climate models of the EURO-CORDEX (Jacob et al. 2014) were used, all exhibiting resolutions of 12 or $50 \mathrm{~km}$. Downscaled scenarios (quantile mapping method) are available for seven of the MAN stations considered here (2AN, 4MO, 4UL, 5WJ, DIS, GRH, GUE), and also as a $2 \times 2 \mathrm{~km}$ grid over Switzerland ( $\mathrm{CH} 2018$ ). For further analysis, we used the scenarios for these seven MAN stations (between 1197 and $2540 \mathrm{~m}$ asl) and for the IMIS stations, we extracted the simulation parameters from this $2 \times 2 \mathrm{~km}$ grid. All simulations provided projections for air temperature, thus $\mathrm{T}_{21 \mathrm{~d}} \geq 5{ }^{\circ} \mathrm{C}$ was estimated accordingly. To account for elevational differences between IMIS locations and grid cells, we applied an air temperature lapse rate of $-0.5 \mathrm{~K}$ per $100 \mathrm{~m}$ increase in altitude (results for lapse rates between -0.2 and $0.8 \mathrm{~K}$ per $100 \mathrm{~m}$ are provided in the Online Resource 4). As the scenarios include projections for precipitation, we deduced $\mathrm{HS}_{\text {mean }}$ from accumulated winter precipitation. For the seven MAN stations, we first determined the sum of the measured daily precipitation starting at 1 October until $\mathrm{T}_{21 \mathrm{~d}} \geq 5^{\circ} \mathrm{C}$ (DOY). We only considered days with daily mean temperatures $\leq 0$ ${ }^{\circ} \mathrm{C}$ during the period between 1982 and 2019. We calculated Pearson correlations of the so derived cumulative precipitation and of the $\mathrm{HS}_{\text {mean }}$ for the seven stations. We then computed a station-specific proportionality factor of the cumulative precipitation in relation to the $\mathrm{HS}_{\text {mean }}$ (mean accumulated precipitation per $\mathrm{cm}$ of snowpack height). For IMIS stations, which commonly do not measure liquid precipitation, we used the mean proportionality factor of the seven MAN stations (1197-2540 m asl).

\subsection{Model validation}

To assess the model's performance, particularly with measured $\mathrm{HS}_{\text {mean }}$ versus parameterised $\mathrm{HS}_{\text {mean }}$ (Eq. 1), we refitted the linear mixed model with empirical data of the seven MAN stations from uneven years only. We subsequentially used the measured and the parametrised 
$\mathrm{HS}_{\text {mean }}$ to predict snowmelt dates of uneven years and compared the model results to the observed snowmelt dates. In a second step, we applied the original model to the reference periods of the climate change scenarios, 1990 to 2019 (MAN), and 2000 to 2019 (IMIS), respectively. For these 30 and 20 years, we compared estimated and observed snowmelt dates as well as trends (Theil-Sen slopes) of the snowmelt date time series (estimated $v s$. observed).

We then projected future changes in snowmelt dates for the three 30-year periods 2020 2049 (beginning of century), 2045-2074 (mid-century), and 2070-2099 (end of century) as well as for the twenty-first century (2020-2099) to achieve future longer-term trends of snowmelt dates, determining the onset of the alpine growing season. All calculations and analyses were performed with R 3.6 (R Core Team 2019).

\section{Results}

\subsection{Comparison of definitions for snow onset and snow melt}

We carefully assessed the suitability of our definitions for snow onset and melt dates. The main snow period at MAN stations was only slightly affected by the maximum number of consecutive snow-free days we allowed for. In $53 \%$ of all cases, snowmelt dates were the same, irrespective of the number of snow-free days. The 5-day-gap we used for further analysis yielded the same snowmelt dates as gaps of 3 days in $86 \%$ of all cases.

Snow onset at both station types at the Weissfluhjoch (Table 1) differed by no more than one day in 11 out of 19 overlapping years. However, late autumn snowfall in two years was classified as part of the main snow period at the MAN station, resulting in a difference of 10 and 17 days compared to the IMIS station. Snowmelt was slightly earlier at the MAN than at the IMIS station, with a median difference of one day, and a maximum difference of four days in 2000 and 2010. This variation in snowmelt dates was most likely caused by microtopographical differences (slight topographical depression at the IMIS station).

\subsection{Trends in snow onset and melt dates: 1958 to 2019}

Out of the 38 stations, 16 MAN stations had continuous snow depth recordings for the past 62 years or more. To assess relevant shifts across time and elevations, we calculated the trends in snow onset and melt dates for the period 1958 to 2019. There was a tendency towards later snow onset that was indicated by persistently positive Theil-Sen slopes. These trends were statistically significant for two stations only: 2ME, 6RI (Table 2). In contrast, there was a clear trend towards earlier snowmelt and for ten stations, this shift was statistically significant $(p<$ 0.05 ). Across all stations, snowmelt on average occurred $2.8 \pm 1.3$ days (mean $\pm \mathrm{sd}$ ) earlier per decade. The magnitude of the trends in snowmelt did not depend on elevation $\left(p=0.46 ; \mathrm{R}^{2}=\right.$ 0.04 ) and at the two stations in the alpine vegetation zone (GUE, 5WJ), snowmelt occurred 3.1 and 4.0 days earlier per decade (Table 2). With 6.3 days per decade, the station 2ME (1320 m asl) showed the most distinct shift in snowmelt dates.

\subsection{Trends in snowmelt dates: 21-years running window trends}

Trends of 21-year running windows revealed the temporal variability of snowmelt date trends between 1946-2009. We required continuous snowmelt date time series of at least 21 years, 
Table 2 Trends (Theil-Sen slopes) for the snow onset and snowmelt dates between 1958 and 2019 with the corresponding $p$-value (Mann-Kendall test)

\begin{tabular}{|c|c|c|c|c|c|}
\hline \multirow{2}{*}{$\begin{array}{l}\text { Station } \\
\text { abbr }\end{array}$} & \multirow{2}{*}{$\begin{array}{l}\text { Site name } \\
\text { Guttannen }\end{array}$} & \multicolumn{2}{|c|}{$\begin{array}{l}\text { Snow onset } \\
\text { Trend 1958-2019 p-value } \\
\left(\text { days decade }^{-1}\right)\end{array}$} & \multicolumn{2}{|c|}{$\begin{array}{l}\text { Snow onset } \\
\text { Trend 1958-2019 p-value } \\
\text { (days decade }{ }^{-1} \text { ) }\end{array}$} \\
\hline & & +0.6 & 0.74 & -3.0 & 0.08 \\
\hline $2 \mathrm{EN}$ & Engelberg & +0.6 & 0.68 & -3.5 & 0.06 \\
\hline $1 \mathrm{GA}$ & Gadmen & +0.5 & 0.64 & -1.2 & 0.26 \\
\hline DIS & Disentis & +1.7 & 0.24 & -1.4 & 0.28 \\
\hline $6 \mathrm{CB}$ & Campo Blenio & +2.2 & 0.14 & -1.5 & 0.14 \\
\hline $1 \mathrm{WE}$ & Wengen & +1.4 & 0.39 & -2.9 & 0.03 \\
\hline $2 \mathrm{ME}$ & Meien & +2.6 & 0.03 & -6.3 & $<0.01$ \\
\hline $4 U L$ & Ulrichen & +1.4 & 0.22 & -2.0 & 0.04 \\
\hline $4 \mathrm{MS}$ & Muenster & +2.4 & 0.09 & -2.7 & 0.02 \\
\hline $2 \mathrm{AN}$ & Andermatt & +1.5 & 0.19 & -3.6 & $<0.01$ \\
\hline $1 \mathrm{~GB}$ & Grindelwald Bort & +1.5 & 0.31 & -2.9 & 0.02 \\
\hline $4 \mathrm{MO}$ & Montana & +0.5 & 0.78 & -3.1 & 0.01 \\
\hline $1 \mathrm{MR}$ & Muerren & +1.2 & 0.34 & -0.8 & 0.42 \\
\hline 6RI & Ritom Piora & +3.0 & 0.02 & -2.8 & 0.01 \\
\hline GUE & Guetsch a) & - & - & -3.1 & 0.01 \\
\hline $5 \mathrm{WJ}$ & Weissfluh-joch & +0.4 & 0.76 & -4.0 & $<0.01$ \\
\hline
\end{tabular}

Positive values indicate a trend towards later in the year, negative values towards earlier in the year. Bold $p$ values indicate statistically significant trends. Stations are ordered from low to high elevation (lowest first)

a) No continuous records for snow onset

excluding the IMIS stations. Our analysis unveiled a period with later snowmelt dates during the 1940 s to 1980 s, but trends were rarely statistically significant. Strikingly, the late 1980 s and early 1990s were denoted by a sharp, significant trend towards earlier snowmelt, with a mean of $15.1 \pm 3.8$ days per decade in 1988 (1978-1998, $\mathrm{n}_{\text {stations }}=21$; Fig. 2). This pattern was evident for nearly all stations and along all elevations, even at the highest location (5WJ, 2540 $\mathrm{m}$ asl). Only two stations (1MR, 6CB) did not show this shift. After the 1990s, trends in snowmelt dates did not exhibit a consistent direction and they were mainly statistically nonsignificant. The clear trend towards earlier snowmelt for the whole period between 1958 and 2019 was caused by the abrupt shift during the late 1980s and early 1990s.

\subsection{Comparison of snowmelt dates at MAN and IMIS stations}

As high-elevation stations were scarce in the past, we compared snowmelt dates of IMIS and MAN station during 2000 and 2019, with measurements for both station types. Between 2000 and 2019, average snowmelt at the IMIS stations (2101-2555 m asl) was in mid-June around the longest day of the year, whereas at the MAN stations (1055$1980 \mathrm{~m}$ asl without GUE and 5WJ) snowmelt occurred in mid-April. The Pearson correlation for the yearly mean snowmelt dates of the two station types was 0.83 $\left(\mathrm{n}_{\text {years }}=20, p<0.01\right.$; Fig. 3). Even without the two MAN stations above $2000 \mathrm{~m}$ asl $\left(5 \mathrm{WJ}\right.$ and GUE), this correlation was strong $\left(0.82, \mathrm{n}_{\text {years }}=20, p<0.01\right)$. This means the changes in snowmelt dates at stations above the climatic treeline (IMIS stations) are closely related to these at lower-elevation MAN stations. There was one exception in 2002 with the second warmest February since the start of measurements at that time, followed by a warm spring, causing early snowmelt at low elevation (12 days earlier than 


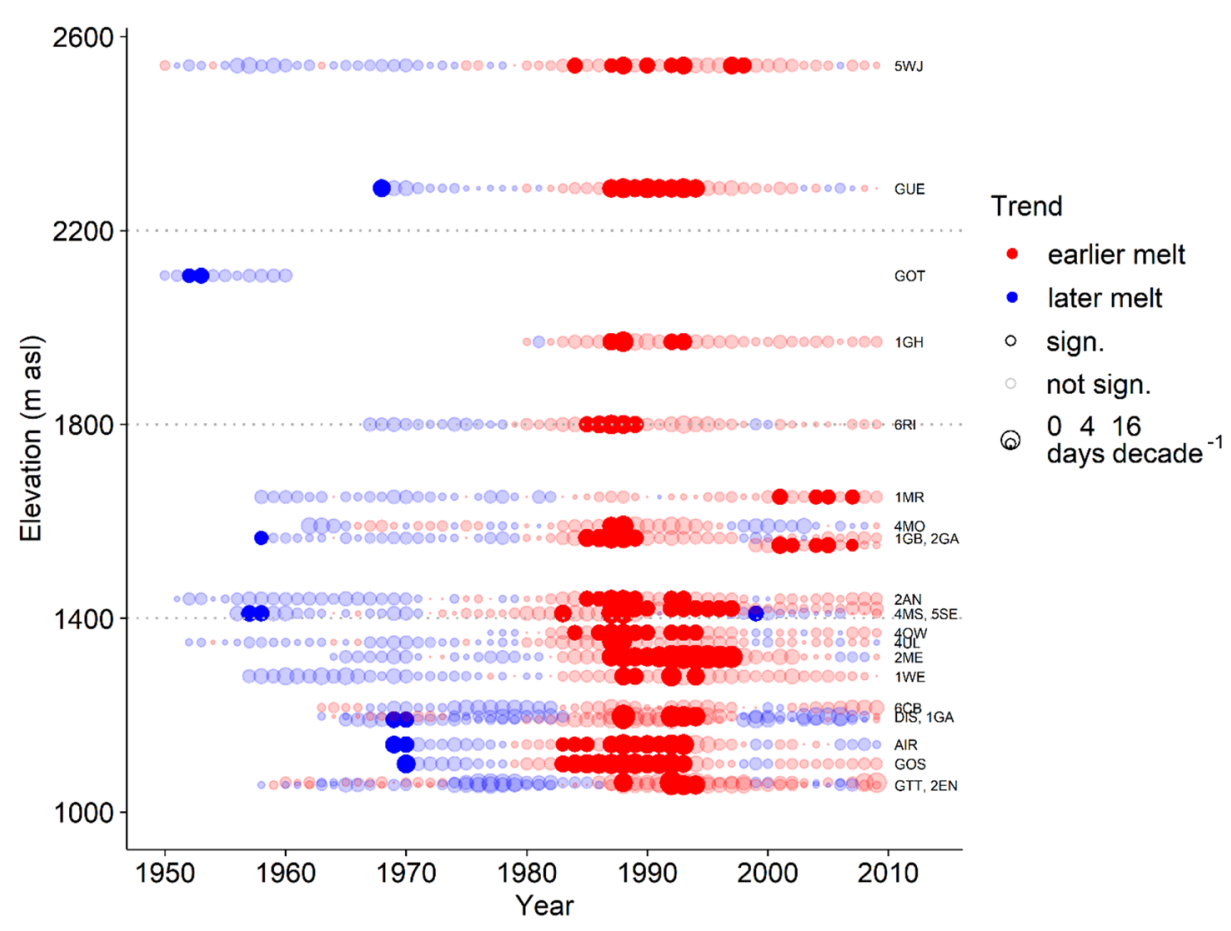

Fig. 2 Snowmelt trends in 21-year running windows at MAN stations, ordered by elevation. The colours indicate the direction of the trend. The symbol size corresponds to the slope of the trend (expressed in days per decade) and opaque fillings represent statistically significant trends at $p<0.05$ (see Table 1 for station abbreviation and full station name, respectively). For instance, a trend for the year 2009 (last dot) corresponds to the Theil-Sen slope for the period 1999 to 2019

the mean at MAN stations). Whereas at high elevation, large precipitation amounts in February, March and May 2002 fell as snow, thus delaying snowmelt (six days later than the mean at IMIS stations).

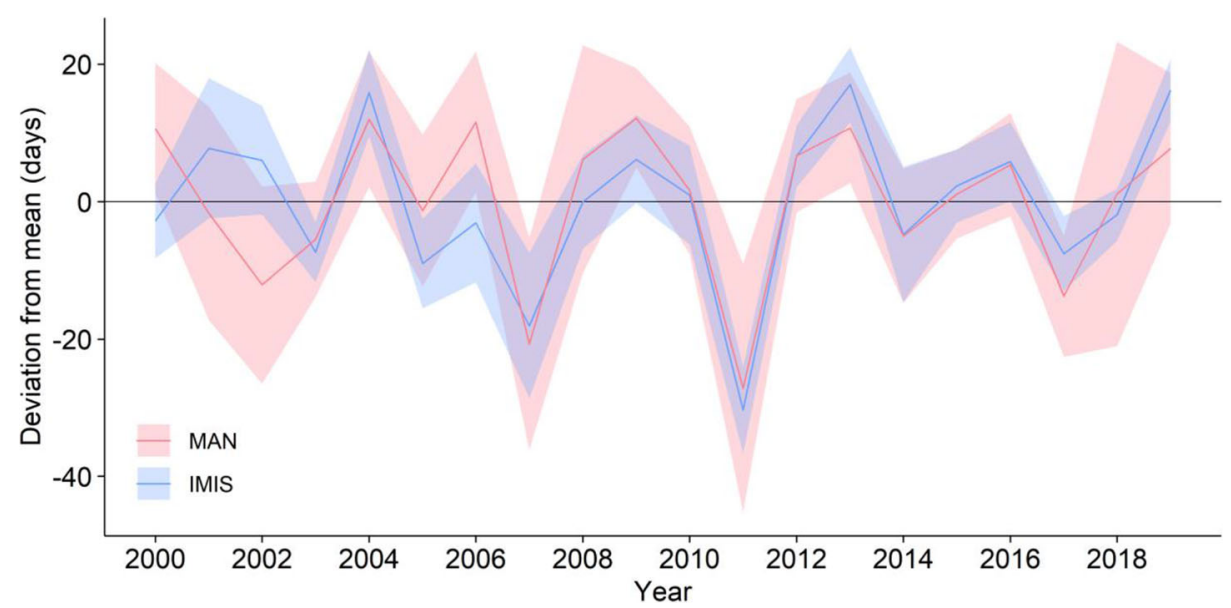

Fig. 3 Yearly deviation of snowmelt dates from the 10-year average (2000-2009) for manual (MAN; (red, $n=$ 22) and automatic (IMIS) stations (blue, $\mathrm{n}=15$; mean [line] $\pm \mathrm{sd}$ [bands]). The deviation at single stations is shown in Online Resource 5 


\subsection{Influence of $\mathrm{HS}_{\text {mean }}$ and temperature on snowmelt dates}

Air temperature and $\mathrm{HS}_{\text {mean }}$, as a proxy for accumulated winter precipitation, directly influenced snowmelt dates along the whole elevational range of the stations. We quantified both effects by analysing snowmelt dates in relation to the observed $\mathrm{T}_{21 \mathrm{~d}} \geq 5^{\circ} \mathrm{C}$ and $\mathrm{HS}_{\text {mean }}$ (Fig. 4; stations at 1055-2540 m asl; variance inflation factor of 1.04). For each week that this $5{ }^{\circ} \mathrm{C}$ threshold was attained earlier, mean snowmelt dates occurred 3.9 days earlier $(\mathrm{a}=0.6$ days day ${ }^{-1}$ in Eq. 1). The model with $\mathrm{T}_{21 \mathrm{~d}} \geq 5^{\circ} \mathrm{C}$ explained $44 \%$ of the variance in snowmelt dates $\left(\mathrm{R}_{\mathrm{c}}^{2}\right.$ 0.81). A higher $\mathrm{HS}_{\text {mean }}$ delayed snowmelt, proportionally to the square root of $\mathrm{HS}_{\text {mean }}$ (Fig. $4 \mathrm{~b} ; \mathrm{b}=4.6$ days $\mathrm{cm}^{-1 / 2}$ in Eq. 1). For instance, an increase of $\mathrm{HS}_{\text {mean }}$ from 40 to $90 \mathrm{~cm}$ caused a delay in snowmelt dates by 14 days, but an increase from 140 to $190 \mathrm{~cm}$ postponed snowmelt by nine days only. In the model with $\mathrm{HS}_{\text {mean }}$ only, still $30 \%$ of the variance in snowmelt dates was explained $\left(\mathrm{R}_{\mathrm{c}}^{2} 0.80\right)$. Together, $\mathrm{T}_{21 \mathrm{~d}} \geq 5^{\circ} \mathrm{C}$ and $\mathrm{HS}_{\text {mean }}$ explained $80 \%$ of the variance in the snowmelt date $\left(\mathrm{R}_{\mathrm{c}}^{2}=0.89\right)$.

\subsection{Snowmelt throughout the twenty-first century}

We projected future snowmelt dates by applying the linear mixed model to the CH2018 Climate Change Scenarios (CH2018 Project Team 2018). For the seven MAN stations with scenarios for temperature and precipitation, $\mathrm{HSS}_{\text {mean }}$ of $100 \mathrm{~cm}$ on average corresponded to an accumulated winter precipitation of $560 \pm 70 \mathrm{~mm}$ (minimum of $460 \mathrm{~mm}$ in $4 \mathrm{MO}$, maximum of $650 \mathrm{~mm}$ at GRH) and disclosing no effect of elevation. The correlation of $\mathrm{HS}_{\text {mean }}$ and the total winter precipitation for the period 1982 to 2019 was high, with Pearson correlation coefficients between 0.74 (DIS) and 0.86 (4UL). Only at the station Guetsch (GUE) it was with 0.65 lower.

Compared to the observed snowmelt dates, the predicted snowmelt dates for even years (model refitted with data of uneven years only) had a standard error of less than one day (0.82 days), highlighting a good model fit. With $\mathrm{HS}_{\text {mean }}$ estimated by the station-specific proportionality factors, the standard error increased by $15 \%$ to 0.94 days.
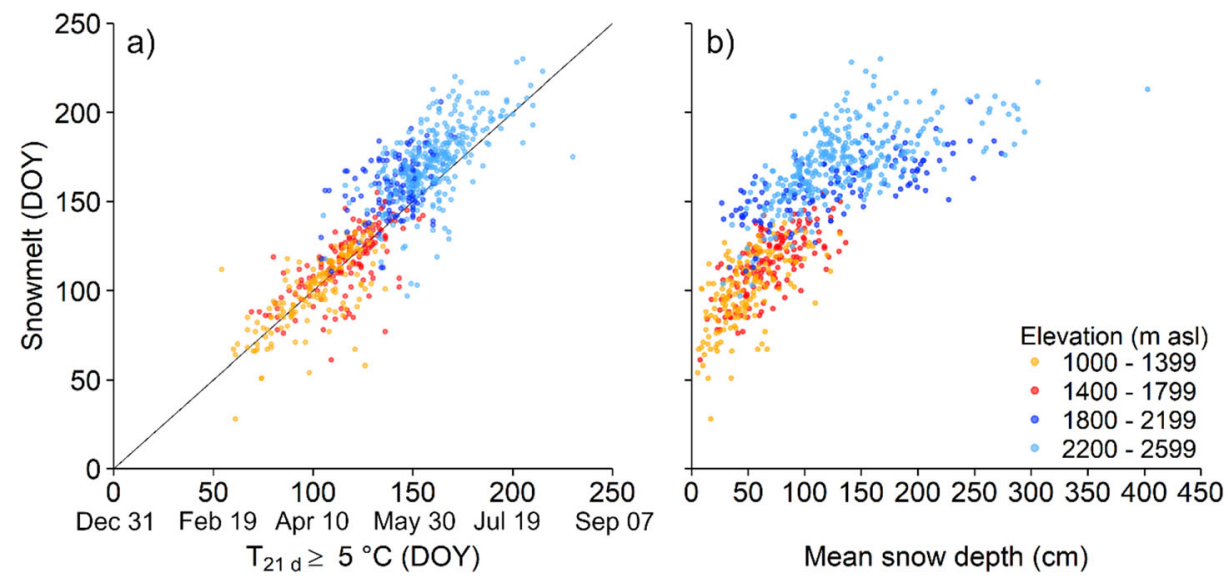

Fig. 4 Snowmelt a) in relation to the first day (day of the year; date) when the running mean air temperature of a 21-day window reaches a threshold of $5{ }^{\circ} \mathrm{C}\left(\mathrm{T}_{21 \mathrm{~d}} \geq 5{ }^{\circ} \mathrm{C}\right)$, and b) in relation to the mean snow depth between snow onset and melt date $\left(\mathrm{HS}_{\text {mean }}\right)$. The 755 data points are from 10 MAN (1941-2019) and 14 IMIS stations (2000-2019), but not every station covers the entire time span) 
For our model validation, we used the reference period of the climate change scenarios: 1990 to 2019 (MAN) and 2000 to 2019 (IMIS). At MAN stations, medians of the observed and simulated snowmelt dates deviated by zero to seven days only. The median snowmelt date of IMIS stations was also well reproduced by the model outputs. Deviations of one (TUJ2) to 14 days (OBW2) were overall larger than at MAN stations, because the model parameters extracted from a $2 \times 2 \mathrm{~km}$ grid did not always mirror the exact station conditions (estimated $v$. observed snowmelt in Online Resource 6). The time series analysis of the observed snowmelt dates revealed no significant trend during the reference period, except for one station (10 days decade $^{-1}$ at TUJ3, $p=0.03$ ). Most $\mathrm{CH} 2018$ simulations for the reference period did not display significant trends in the snowmelt date either. On average $11 \%$ of the simulations at MAN stations featured significant trends towards earlier snowmelt, and 7\% at IMIS stations, but without uniform direction.

After the validation, we simulated the future snowmelt dates based on $\mathrm{CH} 2018$ projections for the beginning of the twenty-first century (2020-2049), for the mid-century (2045-2074), and for the end of the century (2070-2099) as well as the overall trend for the twenty-first century (2020-2099; Fig. 5). The trends of the simulated time series of snowmelt dates within each RCP were relatively concise regarding their direction. A $1000 \mathrm{~m}$ elevational gradient caused a decrease in median snowmelt trends by 0.5 days decade ${ }^{-1}$ only; thus, the magnitude of the effect of elevation was negligible $\left(p=0.17, \mathrm{R}^{2}=0.10\right)$. We here present the rates of change (trends) in snowmelt dates throughout the twenty-first century as the median trend

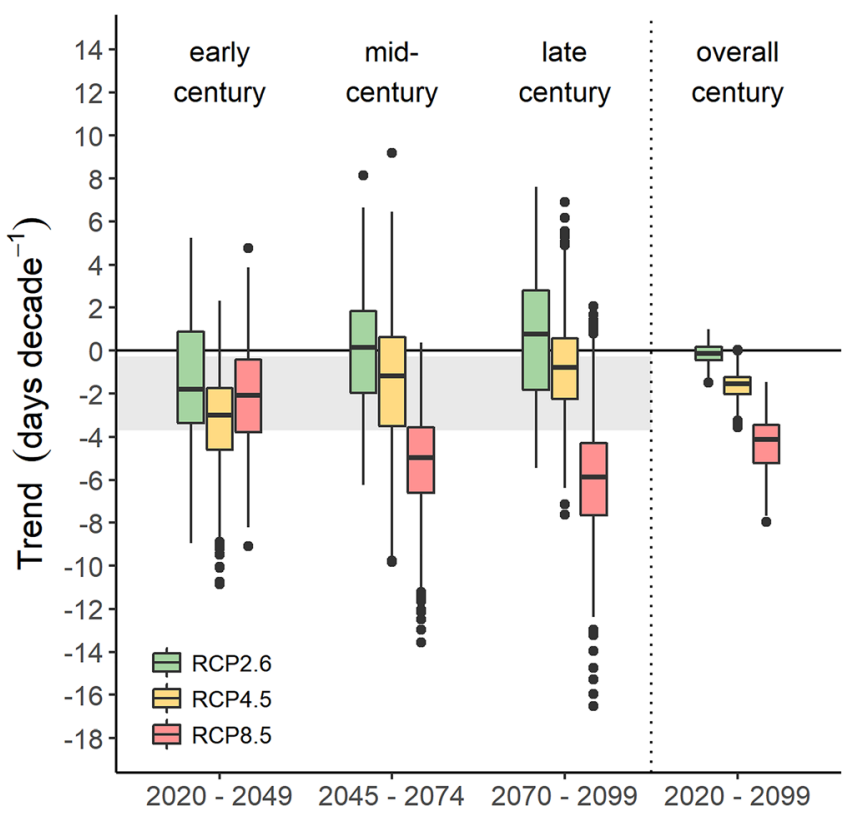

Fig. 5 Projected trends in snowmelt dates of 21 (7 MAN and 14 IMIS) stations throughout the $21^{\text {st }}$ century for the three emission scenarios RCP2.6, RCP4.5 and RCP8.5. In total, 68 simulations based on downscaled regional climate models: 12 for RCP2.6, 25 for RCP4.5, and 31 for RCP8.5, whereby the uneven sample sizes are responsible for the variability of trends between RCP scenarios in the early century. The coloured box contains $50 \%$ of all simulations per RCP scenario and time period. The region shaded in grey indicates the 25 th and 75 th quantile trend during the 30-year period 1990 to 2019 
across stations (7 MAN and 14 IMIS stations) and of a total of 68 simulations (12 for RCP2.6, 25 for RCP4.5, and 31 for RCP8.5). Extreme trends in snowmelt (outliers in Fig. 5) were clearly identifiable as results of single simulations and not because we aggregated stations of different elevations. As there were no large differences in trends between MAN and IMIS stations, we combined the results (Fig. 5), and we rounded our estimations to whole numbers (Table 3).

In RCP2.6, predicted snowmelt dates did not show any change throughout the twenty-first century. Under RCP4.5, median snowmelt dates throughout the century will occur 2 days earlier each decade and $81 \%$ of the trends were statistically significant. This overall trend was mainly caused by a pronounced advancement during the beginning of the century (2020-2049, Fig. 5), with 3 days per decade. This shift dropped to 1 day per decade by the end of the century. For the whole century, the RCP4.5-models projected the median snowmelt date to advance by 10 days by the mid-century, and by 13 days by the end of the century (Table 3 ).

With unabated emissions (RCP8.5), snow will melt 4 days earlier each decade between 2020 and 2099 (trends of all simulations at all stations statistically significant). In contrast to the other two RCP scenarios, we found that snowmelt dates will accelerate over the century. While at the beginning, snowmelt will occur 2 days earlier per decade, towards the end of the century it will be 6 days earlier per decade. Median snowmelt dates will be 14 days earlier in the mid-century and 27 days earlier by the end of the century (Table 3 ).

To further illustrate the effect of these trends, we took a closer look at 2AN at $1440 \mathrm{~m}$ asl, a touristic skiing resort in central Switzerland, and at the two highest IMIS stations BED2 (2450 $\mathrm{m}$ asl) and LUK2 (2555 $\mathrm{m}$ asl). During the reference period (1990-2019), the median snowmelt date in 2AN occurred in late April, and only once before 1 April (2011). Under RCP4.5, snowmelt before April could become normal in one out of 12 winters, and under RCP8.5, this would be the case in one out of four years. At the IMIS stations BED2 and LUK2, the earliest snowmelt was at the beginning of June during 2000 to 2019, and the median snowmelt date was in the first third of July. In one out of four winters, snowmelt will occur in the first half of June (RCP4.5) or even before 1 June (RCP8.5).

Table 3 Projected deviation of snowmelt dates compared to the reference period (MAN 1990-2019, IMIS 20002019; median, $25^{\text {th }}$ and $75^{\text {th }}$ quantiles, expressed as number of days: negative values mean earlier snowmelt, positive later snowmelt) for the future 30-year periods and three RCP scenarios. All values are rounded to whole days

\begin{tabular}{lllll}
\hline Period & Scenario & $\begin{array}{l}\text { Median } \\
\text { (days) }\end{array}$ & $\begin{array}{l}\text { 0.25 quantile } \\
\text { (days) }\end{array}$ & $\begin{array}{l}\text { 0.75 quantile } \\
\text { (days) }\end{array}$ \\
\hline $2020-2049$ & RCP2.6 & -5 & -14 & 4 \\
& RCP4.5 & -5 & -13 & 3 \\
$2045-2074$ & RCP8.5 & -6 & -14 & 2 \\
& RCP2.6 & -6 & -15 & 3 \\
$2070-2099$ & RCP4.5 & -10 & -19 & -2 \\
& RCP8.5 & -14 & -25 & -5 \\
& RCP2.6 & -5 & -14 & -4 \\
& RCP4.5 & -13 & -22 & -16 \\
\hline
\end{tabular}




\section{Discussion}

\subsection{Past trends of snowmelt dates}

Between 1958 and 2019, snowmelt occurred $2.8 \pm 1.3$ days earlier per decade. This was substantially more conservative than the 5.8 days per decade stated by Klein et al. (2016) for the period 1970 to 2015. We could associate these different rates to the specific time periods. Trends in snowmelt dates varied considerably throughout the past decades, as revealed by trends in 21-year running windows. The late 1980s and early 1990s were marked by substantially earlier snowmelt dates. This so-called regime shift manifested itself by earlier snowmelt and caused a $20 \%$ reduction of snow days above $1300 \mathrm{~m}$ asl in Switzerland (Marty 2008). Moreover, rapid climatic shifts during the late 1980s were evident in other datasets worldwide, for example, ocean and air temperatures, sea ice extent and grape ripening dates (Reid et al. 2016). In Switzerland, March to May temperatures increased by $0.39 \mathrm{~K}$ decade $^{-1}$ between 1959 and 2008 (Ceppi et al. 2012), and by $0.84 \mathrm{~K} \mathrm{decade}^{-1}$ in the period 1975 to 2004 (Rebetez and Reinhard 2008), suggesting that spring temperatures caused the regime shift in snowmelt dates described above. For Europe, this regime shift has recently been explained by natural, coincidental anomilies in the atmospheric circulation that were possibly related to the Pacific Decadal Oscillation and the Arctic Oscillation. This short-term warming superimposed a long-term trend of rising temperatures (Sippel et al. 2020). Locally, as for example in Switzerland, the decline of these atmospheric anomalies even led to a (short-term) trend towards lower temperatures (Ceppi et al. 2012; Bader and Fukutome 2015; Saffioti et al. 2016). Indeed, MeteoSwiss highlighted the dominant role of cyclonic low-pressure weather situations over Europe during winters (Dec-Feb) since the 1990s. Accordingly, we do not see any clear trends in snowmelt dates after the regime shift. Colder winters due to large-scale weather phenomena over Europe may thus have masked the recent warming and slowed the retreating snowmelt dates.

\subsection{The role of elevation}

Most studies on snow cover changes (e.g. Laternser and Schneebeli 2003; Scherrer et al. 2004; Marty 2008; Klein et al. 2016) focussed on stations at lower elevation, including only a few in the alpine vegetation belt (e.g. Gr. St. Bernard, Weissfluhjoch). Here, we included the relatively new snow depth series of IMIS stations and clearly demonstrated that the snowmelt dates correlated well with MAN stations, despite the two-months earlier snowmelt dates at lower elevations. We did also not find a pronounced elevational gradient in the trends of snowmelt dates. Scherrer et al. (2004) observed an only weak elevational gradient for the snow days (Dec-Feb) along an elevational gradient between 400 and $2500 \mathrm{~m}$ asl. Laternser and Schneebeli (2003) highlighted that the snow cover duration shortened fastest between 1000 and $1600 \mathrm{~m}$ asl, because temperature increases close to the zero-degree isotherm had the largest impact on the snow cover (Ceppi et al. 2012). The advancement of snowmelt dates at lower elevations may be slowed down by the reduced amount of solar radiation that is available when snowmelt dates recede towards earlier in the year (Musselman et al. 2017). At higher elevations, where the snowpack may persist beyond the mid-summer, receding snowmelt dates may move to a time with highest solar radiation and thermal energy and trends may therefore be accelerated (Essery et al. 2020).

Counter to our expectations, our proportionality factor describing the relation of winter precipitation to $\mathrm{HS}_{\text {mean }}$ was unaffected by elevation. We would have assumed a temperature dependence, due to a higher fraction of liquid precipitation at lower elevations. However, 
under-catch and wind-induced snow redistribution at high elevations may potentially balance out the effect of an elevational gradient.

The RCP scenarios displayed slightly more moderate trends at higher elevations, but with less than 0.5 days decade ${ }^{-1}$ for $1000 \mathrm{~m}$ elevational difference, this was negligible.

\subsection{Effect of temperature and precipitation on snowmelt dates}

Temperature and precipitation, the two key factors for determining snowmelt dates, are highly affected by climate change (IPCC 2013). Morán-Tejeda et al. (2013) emphasised temperature as the driving factor for the snowpack duration below $1200 \mathrm{~m}$ asl. Above this elevation, accumulated precipitation and the winter-history of temperature and precipitation were more influential. For snowmelt, we found $\mathrm{T}_{21 \mathrm{~d}} \geq 5^{\circ} \mathrm{C}$ to be 1.5 times more influential than the precipitation proxy $\mathrm{HS}_{\text {mean }}$. Moreover, snowmelt dates related to the square-root of $\mathrm{HS}_{\text {mean }}$, revealing a decreasing influence of snow depth at higher elevations. Our measures for temperature and precipitation thus differed from monthly mean air temperatures and accumulated precipitation considered in Morán-Tejeda et al. (2013). $\mathrm{T}_{21 \mathrm{~d}} \geq 5{ }^{\circ} \mathrm{C}$ represents a threshold when temperatures are high enough for the whole snowpack to melt. Although $\mathrm{HS}_{\text {mean }}$ correlates with accumulated winter precipitation, it does not always directly relate to monthly precipitation. Both our measures account for the temperature and precipitation history during winter.

\subsection{Snowmelt dates throughout the twenty-first century}

Accelerating snowmelt dates above the climatic treeline can only be halted by abating emissions enormously, as our simulations predict a roughly one-month earlier snowmelt for RCP8.5 and two-week earlier snowmelt for RCP4.5 by the end of the twenty-first century. Compared to previous projections of snow cover changes, our estimations are rather conservative. Bavay et al. (2009) projected snowmelt dates in eastern Switzerland to occur 40 days earlier by the end of the century, and in the large Aare catchment $\left(3190 \mathrm{~km}^{2}\right)$ the snow duration at $2000 \mathrm{~m}$ asl may shorten by 2.5 months compared to the reference period (1999-2012; Marty et al. 2017). Such early melt could be interpreted as a direct consequence of lower snow depth and snow water equivalents, as simulated by Schmucki et al. (2015b) and Steger et al. (2013). In contrast to these studies, our model is fully based on empirical observations and not on physical processes. Our data used for model fitting covered a period with massive changes in snowmelt dates; nevertheless, the relation of $\mathrm{T}_{21 \mathrm{~d}} \geq 5{ }^{\circ} \mathrm{C}$ and $\mathrm{HS}_{\text {mean }}$ to the snowmelt date was robust.

\subsection{Consequences for alpine plants}

Our simulation results also enable us to put alpine snow manipulation experiments into the context of climate change scenarios. Some experiments realised 18-day earlier snowmelt dates by reducing the snow depth in spring, summarised by Wipf and Rixen (2010). Under RCP8.5, these experiments would thus reproduce conditions we may observe in the mid-century (2045-2074).

A one-month earlier snowmelt may expand the alpine growing season by more than one third by the end of the century (RCP8.5), most likely with drastic consequences for alpine plants. These may include lower flower numbers, reduced leaf growth and a lower survival, as observed for the evergreen forb Gentiana nipponica by a one-month earlier snowmelt (Kawai and Kudo 2018), and snowbed species produced less seeds after an earlier snowmelt of 18 days (Tonin et al. 2019). According to an experiment with 23 nival and alpine species, it is assumed that one third 
to one half the alpine flora may be sensitive to photoperiod and hence may not profit from a longer growing season because of too short daylengths (Keller and Körner 2003). The 4h-difference in daylength they applied in the greenhouse study is comparable to snowmelt in mid-March instead of late June, a shift of roughly three months. Such a shift exposes plants to higher frost risks. Recurrent frosts killed flower buds in alpine herbs (Inouye 2008), impaired growth snowbed species (Baptist et al. 2010b) as well as in three dwarf shrub species (Wipf et al. 2009). Francon et al. (2020) further suggested a strong elevational impact, disclosed by growth ring analysis of the shrub Rhododendron ferrugineum. Longer growing seasons at $2400 \mathrm{~m}$ asl enhanced its growth, while at 1800 and $2000 \mathrm{~m}$ asl early snowmelt dates led to frosts and ultimately limited growth.

Because a one-month earlier snowmelt will not reduce the daylength sufficiently for photoperiod restrictions, we assume that in the long-term, frost events at the beginning of the growing season will play a bigger role than photoperiod limitations and may diminish the effect of longer growing seasons.

\section{Conclusions}

We show a high correlation between snowmelt dates at high-elevation IMIS stations and lower-elevation MAN stations, implying that snowmelt dates are advancing with similar rates along an elevational gradient of $1000 \mathrm{~m}$ asl to $2500 \mathrm{~m}$ asl in the Swiss Alps. Our empirical approach highlighted the dominant effect of temperature over a slightly weaker influence of mean snow depth $\left(\mathrm{HS}_{\text {mean }}\right)$ on snowmelt dates. With $\mathrm{T}_{21 \mathrm{~d}} \geq 5{ }^{\circ} \mathrm{C}$, we found an appropriate temperature measure that correlated well with snowmelt dates at different elevations. By applying both, $\mathrm{T}_{21 \mathrm{~d}} \geq 5{ }^{\circ} \mathrm{C}$ and $\mathrm{HS}_{\text {mean }}$ to $\mathrm{CH} 2018$ Climate Change Scenarios, we could anticipate snowmelt dates throughout the twenty-first century.

By the end of the century, we expect an earlier snowmelt by up to one month. Such an early melt will affect hydropower production, winter tourism in the Swiss Alps and will expose the alpine flora and soils to a higher frost risk with additional consequences on biogeochemical cycles.

Supplementary Information The online version contains supplementary material available at https://doi.org/ 10.1007/s10584-021-03027-x.

Acknowledgments We thank MeteoSwiss and SLF for providing the daily snow depth, temperature and precipitation data, and we are grateful to Christian Körner for his helpful comments on the manuscript.

Authors' contribution CM, EH and MV all contributed to the study design, MV analysed the data and AK, $\mathrm{CM}, \mathrm{EH}$ and $\mathrm{MV}$ wrote the manuscript.

Funding Open Access funding provided by Universität Basel (Universitätsbibliothek Basel). This project was funded by the Mercator foundation through the support of the Zurich Basel Plant Science Center (PSC, 'Bridging Plant Science and Society'). Further funds came from the Department of Environmental Sciences of the University of Basel.

Code availability The code for retrieving snow onset and melt dates from the daily snowpack height at IMIS stations is provided in the ESM. 


\section{Declarations}

Conflict of interest The authors declare that they have no conflict of interest.

Open Access This article is licensed under a Creative Commons Attribution 4.0 International License, which permits use, sharing, adaptation, distribution and reproduction in any medium or format, as long as you give appropriate credit to the original author(s) and the source, provide a link to the Creative Commons licence, and indicate if changes were made. The images or other third party material in this article are included in the article's Creative Commons licence, unless indicated otherwise in a credit line to the material. If material is not included in the article's Creative Commons licence and your intended use is not permitted by statutory regulation or exceeds the permitted use, you will need to obtain permission directly from the copyright holder. To view a copy of this licence, visit http://creativecommons.org/licenses/by/4.0/.

\section{References}

Bader S, Fukutome S (2015) Milde und kalte Bergwinter [Mild and cold mountain winters]. Fachbericht MeteoSchweiz 254:1-10

Baptist F, Flahaut C, Streb P, Choler P (2010a) No increase in alpine snowbed productivity in response to experimental lengthening of the growing season. Plant Biol 12:755-764. https://doi.org/10.1111/j.14388677.2009.00286.x

Baptist F, Yoccoz NG, Choler P (2010b) Direct and indirect control by snow cover over decomposition in alpine tundra along a snowmelt gradient. Plant Soil 328:397-410. https://doi.org/10.1007/s11104-009-01 19-6

Bartoń K (2020) MuMIn: multi-model inference. R package version 1.43.15. https://cran.r-project.org/package= MuMIn

Bavay M, Lehning M, Jonas T, Löwe H (2009) Simulations of future snow cover and discharge in Alpine headwater catchments. Hydrol Process 23:95-108. https://doi.org/10.1002/hyp.7195

Beniston M, Stoffel M, Giacona F, Farinotti D, Andreassen LM, Magnusson J, Coppola E, Fantini A, Eckert N, Naaim M, Hauck C, Huss M, Huwald H, Lehning M, Marty C, López-Moreno JI, Morán-Tejéda E, Morin S, Provenzale A, Rabatel A, Six D, Vincent C, Stötter J, Strasser U, Terzago S (2018) The European mountain cryosphere: a review of its current state, trends, and future challenges. Cryosphere 12:759-794

Buchmann M, Begert M, Brönnimann S, Marty C (2020) Evaluating the robustness of snow climate indicators using a unique set of parallel snow measurement series. Int J Climatol 1-11. https://doi.org/10.1002/joc.6863

Ceppi P, Scherrer SC, Fischer AM, Appenzeller C (2012) Revisiting Swiss temperature trends 1959-2008. Int J Climatol 32:203-213. https://doi.org/10.1002/joc.2260

CH2018 Project Team (2018) CH2018 - Climate Scenarios for Switzerland. Technical Report, National Centre for Climate Service. https://doi.org/10.18751/Climate/Scenarios/CH2018/1.0

CH2018 (2018) CH2018 Climate change scenarios for Switzerland - Technical report, National Centre for Climate Services. Zurich, p 271. https:/www.nccs.admin.ch/nccs/en/home/climate-change-and-impacts/ swiss-climate-change-scenarios/technical-report.html

Cryer JD, Chan K-S (2008) Time series analysis with applications in R, 2nd edn. Springer, New York

Edwards AC, Scalenghe R, Freppaz M (2007) Changes in the seasonal snow cover of alpine regions and its effect on soil processes: a review. Quat Int 162 \& 163:172-181. https://doi.org/10.1016/j.quaint.2006.10.027

Essery R, Kim H, Wang L, Bartlett P, Boone A, Brutel-Vuilmet C, Burke E, Cuntz M, Decharme B, Dutra E, Fang X, Gusev Y, Hagemann S, Haverd V, Kontu A, Krinner G, Lafaysse M, Lejeune Y, Marke T, Marks D, Marty C, Menard C, Nasonova O, Nitta T, Pomeroy J, Schaedler G, Semenov V, Smirnova T, Swenson S, Turkov D, Wever N, Yuan H (2020) Snow cover duration trends observed at sites and predicted by multiple models. Cryosph Discuss. https://doi.org/10.5194/tc-2020-182

Francon L, Corona C, Till-Bottraud I, Choler P, Carlson BZ, Charrier G, Améglio T, Morin S, Eckert N, Roussel E, Lopez-Saez J, Stoffel M (2020) Assessing the effects of earlier snow melt-out on alpine shrub growth: the sooner the better? Ecol Indic 115:1-13. https://doi.org/10.1016/j.ecolind.2020.106455

Freppaz M, Celi L, Marchelli M, Zanini E (2008) Snow removal and its influence on temperature and N dynamics in alpine soils (Vallée d'Aoste, northwest Italy). J Plant Nutr Soil Sci 171:672-680. https://doi.org/ 10.1002/jpln.200700278

Heide OM (2001) Photoperiodic control of dormancy in Sedum telephium and some other herbaceous perennial plants. Physiol Plant 113:332-337. https://doi.org/10.1034/j.1399-3054.2001.1130305.x 
Hock R, Rasul G, Adler C, Cáceres B, Gruber S, Hirabayashi Y, Jachson M, Kääb A, Kang S, Kutuzov S, Milner A, Molau U, Morin S, Orlove B, Steltzer H (2019) High mountain areas. In: Pörtner H-O, Roberts DC, Masson-Delmotte V, et al. (eds) IPCC Special Report on the Ocean and Cryosphere in a Changing Climate. pp 131-202. https://www.ipcc.ch/srocc/chapter/chapter-2/

Hülber K, Winkler M, Grabherr G (2010) Intraseasonal climate and habitat-specific variability controls the flowering phenology of high alpine plant species. Funct Ecol 24:245-252. https://doi.org/10.1111/j.13652435.2009.01645.x

IPCC (2013) Climate change 2013 The Physical Science Basis, Working group I contribution to 5th assessment report of the intergovernmental panel on climate change. https://www.ipcc.ch/report/ar5/wg1/

Jacob D, Petersen J, Eggert B, Alias A, Christensen OB, Bouwer LM, Braun A, Colette A, Déqué M, Georgievski G, Georgopoulou E, Gobiet A, Menut L, Nikulin G, Haensler A, Hempelmann N, Jones C, Keuler K, Kovats S, Kröner N, Kotlarski S, Kriegsmann A, Martin E, van Meijgaard E, Moseley C, Pfeifer S, Preuschmann S, Radermacher C, Radtke K, Rechid D, Rounsevell M, Samuelsson P, Somot S, Soussana JF, Teichmann C, Valentini R, Vautard R, Weber B, Yiou P (2014) EURO-CORDEX: new high-resolution climate change projections for European impact research. Reg Environ Chang 14:563-578. https://doi.org/ $10.1007 / \mathrm{s} 10113-013-0499-2$

Kawai Y, Kudo G (2018) Variations in ramet performance and the dynamics of an alpine evergreen herb, Gentiana nipponica, in different snowmelt conditions. Am J Bot 105:1813-1823. https://doi.org/10.1002/ ajb2.1186

Keller F, Körner C (2003) The role of photoperiodism in alpine plant development. Arctic, Antarct Alp Res 35: 361-368. https://doi.org/10.1657/1523-0430(2003)035[0361:TROPIA]2.0.CO;2

Klein G, Vitasse Y, Rixen C, Marty C, Rebetez M (2016) Shorter snow cover duration since 1970 in the Swiss Alps due to earlier snowmelt more than later snow onset. Clim Change 139:637-549. https://doi.org/10. 1007/s10584-016-1806-y

Körner C (2003) Alpine plant life. Functional plant ecology of high mountain ecosystems, 3nd edn. Springer, Cham, p 515

Körner C, Riedl S, Keplinger T, Richter A, Wiesenbauer J, Schweingruber F, Hiltbrunner E (2019) Life at $0{ }^{\circ} \mathrm{C}$ : the biology of the alpine snowbed plant Soldanella pusilla. Alp Bot 129:63-80. https://doi.org/10.1007/ s00035-019-00220-8

Laternser M, Schneebeli M (2003) Long-term snow climate trends of the Swiss Alps (1931-99). Int J Climatol 23:733-750. https://doi.org/10.1002/joc.912

Marty C (2008) Regime shift of snow days in Switzerland. Geophys Res Lett 35:L12501. https://doi.org/10. 1029/2008GL033998

Marty C, Meister R (2012) Long-term snow and weather observations at Weissfluhjoch and its relation to other high-altitude observatories in the Alps. Theor Appl Climatol 110:573-583. https://doi.org/10.1007/s00704012-0584-3

Marty C, Schlögl S, Bavay M, Lehning M (2017) How much can we save? Impact of different emission scenarios on future snow cover in the Alps. Cryosph 11:517-529. https://doi.org/10.5194/tc-11-517-2017

Morán-Tejeda E, López-Moreno JI, Beniston M (2013) The changing roles of temperature and precipitation on snowpack variability in Switzerland as a function of altitude. Geophys Res Lett 40:2131-2136. https://doi. org/10.1002/grl.50463

Musselman KN, Clark MP, Liu C, Ikeda K, Rasmussen R (2017) Slower snowmelt in a warmer world. Nat Clim Chang 7:214-219. https://doi.org/10.1038/nclimate3225

Pohlert T (2020) trend: non-parametric trend tests and change-point detection. R package version 1.1.2. https:// cran.r-project.org/package=trend

Prock S, Körner C (1996) A Cross-continental comparison of phenology, leaf dynamics and dry matter allocation in Arctic and temperate zone herbaceous plants from contrasting altitudes. Ecol Bull 45:93-103

R Core Team (2019) R: A language and environment for statistical computing. R Foundation for Statistical Computing, Vienna

Rebetez M, Reinhard M (2008) Monthly air temperature trends in Switzerland 1901-2000 and 1975-2004. Theor Appl Climatol 91:27-34. https://doi.org/10.1007/s00704-007-0296-2

Reid PC, Hari RE, Beaugrand G, Livingstone DM, Marty C, Straile D, Barichivich J, Goberville E, Adrian R, Aono Y, Brown R, Foster J, Groisman P, Hélaouët P, Hsu HH, Kirby R, Knight J, Kraberg A, Li J, Lo TT, Myneni RB, North RP, Pounds JA, Sparks T, Stübi R, Tian Y, Wiltshire KH, Xiao D, Zhu Z (2016) Global impacts of the 1980s regime shift. Glob Chang Biol 22:682-703. https://doi.org/10.1111/gcb.13106

Saffioti C, Fischer EM, Scherrer SC, Knutti R (2016) Reconciling observed and modeled temperature and precipitation trends over Europe by adjusting for circulation variability. Geophys Res Lett 43:8189-8198. https://doi.org/10.1002/2016GL069802

Scherrer SC, Appenzeller C, Laternser M (2004) Trends in Swiss Alpine snow days: The role of local- and largescale climate variability. Geophys Res Lett 31:L13215. https://doi.org/10.1029/2004GL020255 
Scherrer SC, Wüthrich C, Croci-Maspoli M, Weingartner R, Appenzeller C (2013) Snow variability in the Swiss Alps 1864-2009. Int J Climatol 33:3162-3173. https://doi.org/10.1002/joc.3653

Schmucki E, Marty C, Fierz C, Weingartner R, Lehning M (2015a) Impact of climate change in Switzerland on socioeconomic snow indices. Theor Appl Climatol 127:875-889. https://doi.org/10.1007/s00704-015-1676-7

Schmucki E, Marty C, Fierz C, Lehning M (2015b) Simulations of $21^{\text {st }}$ century snow response to climate change in Switzerland from a set of RCMs. Int J Climatol 35:3262-3273. https://doi.org/10.1002/joc.4205

Sippel S, Fischer EM, Scherrer SC, Meinshausen N, Knutti R (2020) Late 1980s abrupt cold season temperature change in Europe consistent with circulation variability and long-term warming. Environ Res Lett 15: 094056. https://doi.org/10.1088/1748-9326/ab86f2

Steger C, Kotlarski S, Jonas T, Schär C (2013) Alpine snow cover in a changing climate: a regional climate model perspective. Clim Dyn 41:735-754. https://doi.org/10.1007/s00382-012-1545-3

Tonin R, Gerdol R, Tomaselli M, Petraglia A, Carbognani M, Wellstein C (2019) Intraspecific functional trait response to advanced snowmelt suggests increase of growth potential but decrease of seed production in snowbed plant species. Front Plant Sci 10:1-12. https://doi.org/10.3389/fpls.2019.00289

Westaway R (2000) Modelling the potential effects of climate change on the Grande Dixence hydro-electricity scheme, Switzerland. Water Environ 14:179-185

Wipf S, Rixen C (2010) A review of snow manipulation experiments in arctic and alpine tundra ecosystems. Polar Res 29:95-109. https://doi.org/10.1111/j.1751-8369.2010.00153.x

Wipf S, Stoeckli V, Bebi P (2009) Winter climate change in alpine tundra: plant responses to changes in snow depth and snowmelt timing. Clim Change 94:105-121. https://doi.org/10.1007/s10584-009-9546-X

Publisher's note Springer Nature remains neutral with regard to jurisdictional claims in published maps and institutional affiliations.

\section{Affiliations}

\section{Maria Vorkauf $^{1} \cdot$ Christoph Marty $^{2} \cdot$ Ansgar Kahmen $^{1} \cdot$ Erika Hiltbrunner $^{1}$}

Christoph Marty

marty@slf.ch

Ansgar Kahmen

ansgar.kahmen@unibas.ch

Erika Hiltbrunner

erika.hiltbrunner@unibas.ch

1 Department of Environmental Sciences, Botany, University of Basel, Schönbeinstrasse 6, 4056 Basel, Switzerland

2 WSL Institute for Snow and Avalanche Research SLF, Flüelastrasse 11, 7260 Davos Dorf, Switzerland 